\title{
THE EFFECT OF BOARD INDEPENDENCE, BOARD SIZE, AND CEO DUALITY ON JORDANIAN FIRM PERFORMANCE
}

\author{
Ahmad Rajab Jwailes ${ }^{1 *}$ \\ ${ }^{*}$ Faculty of Business and Management, Universiyi Sultan Zainal Abidin Kuala Terengganu, Malaysia
}

*Corresponding Author: -

Email: ahmad.jw.les@gmail.com

\begin{abstract}
: -
Board of director characteristics plays a major role in the firms' performance. From those characteristics, board independence, the board size, and CEO duality were found to be effective in many studies. Therefore, this particular study is an examination of the relationships between three antecedents; board independence, the board size, and CEO duality; and the firms' performance among the Jordanian listed firms. This study is composing a predictive model of Tobin's $Q$ based on three BoD antecedents as the independent variables. The regression model has the board independence, board size, and CEO duality as predictors of Tobin's Q. This article is based on quantitative methods that used regression-based analysis for secondary panel data in the context of the Amman Stock Exchange (ASE). The time span is 10 years from 2008 to 2018 and 180 firms from the non-financial sector are included. The results revealed that the three relationships in the proposed model were found to be significant with board size having the highest negative impact, followed by CEO duality the board independence and both have a positive impact. The study can explain 62.64\% of Tobin's $Q$ variance based on three corporate governance variables that are based on the board of directors' structure. In the future, adding more corporate governance variables such as ownership structure, board meetings, and audit committees will contribute to the proposed conceptual framework.
\end{abstract}

Keywords: - Board Independence; Board Size; CEO Duality; Tobin's $Q$

\section{(c) $($ ) (1)}




\subsection{INTRODUCTION}

The governance of the organization is found to be essential in any organization especially those listed in the exchange markets. Corporate governance is assured by many studies to improve the firms' performance especially from the financial and economic point of view (Arslan \& Alqatan, 2020; Srivastava \& Kathuria, 2020). Kyere and Ausloos (2021) conducted a study among listed companies in the UK and reported that different factors of corporate governance will contribute to the improvement of financial performance. The organization with excellent corporate governance will have better financial performance and for sure provides supports for all the organization stakeholders, including investors, managers, and other parties (Alnajar, 2021). A board of directors (BoD) is actually a chosen team of individuals that represent investors. The board is a regulating physical body that generally fulfills at frequent intervals to establish plans for corporate control and also management. In the stock market, every listed company must have a board of directors (Arora, 2015; Liu H. \& Fong, 2010). Therefore, corporate governance in terms of the board of directors' qualities has an influence on the firms' performance especially by using qualities such as board independence, the board size, and also CEO duality (Arora, 2015; Puni \& Anlesinya, 2020).

Resource dependence theory supports the rationale of the board of directors' impact on the firms' performance because the $\mathrm{BoD}$ is one of the essential innovative and critical resource of any organisation, considering that the BoD is accountable for providing and selecting imaginative choices to improve the performance, such as improving proficiency, building exterior relations, providing guidance, and the organisation image (Bathula, 2008). Depending on to the agency theory, the excellence of corporate governance strengthens and also enriches organization's performance through using the monitoring companies right, and assisting their competence to the company and investor's enthusiasm. The directors' panel plays a vital role in effective decision and problem solving. For instance, CEO - chairman separation will increase the transparency and increase the quality of auditing and monitoring (A. Amran, Ishak, Zulkafli, \& Nejati, 2010; Chandren, Qaderi, \& Ghaleb, 2021; Makhlouf, Laili, Ramli, \& Basah, 2017). Through these tasks, the boards of directors with best characteristics will be able to execute a significant economic duty and make a tactical decision making in order to improve the organisation performance especially from the finanicial point of view (Ahmadi, Nakaa, \& Bouri, 2018; Fama \& Jensen, 1983).

In Middle East nations, the event of revolutions besides the financial crises recalls the importance of the BoD in improving the performance of the companies especially the stock listed companies (Fulgence, 2021). In particular to the Jordanian context, there are three reasons to re-examine the relationships between the board of directors characteristics and the firms' performance as the following:

- In 2012, a detraction involving the Jordan Phosphate Mines Company (JPMC) occurred due to the misuse of the workplace by the chairman and the disregarding of several of the facets of board administration (Khorma, 2014).

- The Jordanian economy has actually been affected by the revolution in the Arab area. Many investors relocated their capitalists outside the country, which subsequently, influenced the performance of the companies especially the listed ones (Almasarwah, 2015).

- The majority of the previous studies that investigated this relationship in Jordan used older datasets that were conducted before 2009, the adoption of the "Jordanian Corporate Governance Code (JCGC)".

Besides the previous reasons, the context of the Jordan market has some special characteristics. The market capital in Jordan is small because the country is a small developing one in the Middle East area with a different legal framework and the ownership structure is highly affected by the ownership concentration even in the stock market (Warrad, Almahamid, Slihat, \& Alnimer, 2013).

Despite all economic troubles as well as political disorders which neighbored the Middle East and especially Jordan, substantial progress has been actually detected in the national economic condition, notable growths in the assortment of identified companies in Amman Stock Exchange, increasing in exchanging quantities lately. Significant initiatives have been issued through the Jordanian federal authorities to produce the worldwide financiers and also aid the economic situation of the nation integrate with the worldwide economic environment; for example, the funding markets were liberalized, the rules of enhancing declaration, obligation as properly as openness is actually presented besides to the change in the corporate governance (Idris, 2012; Marashdeh, 2014).

The BoD means an organizational tactical source, thinking that the panel is accountable for enhancing and also choosing inventive choices in the renovation of the business, such as enhancing skills, constructing exterior connections, offering direction, as well as the organization's image (Bathula, 2008). Matar and also Nauimat (2014) stated that the carrying out of control bodies is still weak in Jordan, and likewise, this resulted in a noneffective panel. This influences tactical policymaking, along with hence adversely affects the overall performance (Arora \& Sharma, 2016; Bathula, 2008). Few studies had been conducted among the Jordanian companies about factors of board management (Al-Kassar \& Al-Nidawiy, 2014; Al Ramahi, Alaboud, Owais, AlRefae, \& Shahwan, 2014).

As discussed board of director, characteristics plays a major role in the firms' performance (Al-ahdal, Alsamhi, Tabash, \& Farhan, 2020; Assenga, Aly, \& Hussainey, 2018; Naciti, 2019). From those characteristics, board independence is one of the most effective factors (Uribe-Bohorquez, Martínez-Ferrero, \& García-Sánchez, 2018), board size has an effective impact in many different studies (Naseem, Xiaoming, Riaz, \& Rehman, 2017), and CEO duality is also found to be effective in many studies (Mubeen, Han, Abbas, \& Hussain, 2020). Therefore, this 
particular study is an examination of the relationships between three antecedents; board independence, the board size, and CEO duality; and the firms' performance among the Jordanian listed firms.

\subsection{Development of Hypothesis and Literature}

A board of directors (BoD) is actually a chosen team of individuals that represent investors. The board is a regulating physical body that generally fulfills at frequent intervals to establish plans for corporate control and also management. In the stock market, every listed company must have a board of directors. The Board of directors' qualities and firm performance relationship have been investigated by many scholars; board independence, the board size, and also CEO duality is the chosen variables for this particular study.

\subsection{Board Independence}

To become helpful, boards must take measures, both in their constructs and also in their nominating treatments, to make sure that experts and also exec owners are unable to exercise unnecessary command over the board's activities and choices. Board independence is the condition through which all or a large number of the members of a board of directors do certainly not possess a relationship along with the company except as directors. They might not be actual relatives of the firm's founders, significant workers, or essential players (Naseem, Xiaoming, et al., 2017). The duty of board independence comes to be more crucial in specified business in both developed and developing markets given that an independent large number on the board is very likely to look at the most ideal passions of shareowners, to begin with. It is most likely to cultivate individual decision-making as well as to reduce problems of interest that may arise (Makhlouf, Laili, Ramli, \& Basah, 2017). The relationship between BoD independence and firm performance has mixed results as some studies show negative impact and other studies show a positive impact. However, based on the resource dependence theory, the panels along with individual directors can have a better investigation for the organization's problems and can take a faster and reliable decision making. In addition, the independent directors will provide unbiased monitoring and make professional auditing (Lutfi, Iramani, \& MellyzaSilvy, 2014; Chandren, Qaderi, \& Ghaleb, 2021). Besides, the stewardship theory supports the rationale of board independence because it is assumed that they will have a better experience, which will provide better governance (Aduda, Chogii, \& Magutu, 2013). There are different studies such as those conducted by Al- ahdal et al. (2020), Naciti (2019), Uribe-Bohorquez et al. (2018) found that the more BoD independence, the better organizational performance especially in the financial performance of listed companies Also, Chu, Mathieu, and Mbagwu (2019) conducted a study to measure the impact to the bankruptcy of financial institutes and found a strong relationship to the BoD independence. Based on the above discussions, this particular study hypothesized the following argument.

H1: Board independence has a significant positive relationship with the firm performance in listed companies in Jordan

\subsection{Board size}

Board size describes the overall number of directors on the panel of each organization which is composed of the CEO and also Chairman, outsider directors, corporate directors, and also non-executive directors for each and every financial year. From the agency theory's standpoint, the directors' panel plays a vital role in the effective decision and problem-solving. Small boards are actually most likely to act and determine on the weak performance of CEO; besides to invest less attend discussions and bring in faster decisions. When the board size is small, directors are more committed, genuine, and also interacted (Al Sawalqa, 2021; Alshirah, Abdul Rahman, \& Mustapa, 2020). However, the resource dependence theory point of view revealed a contradictory interpretation as the more members on the $\mathrm{BoD}$ the more experience and expertise, which is supposed to improve the organizational performance (Dhamadasa, Gamage, \& Herath, 2014). Therefore, prior empirical results revealed mixed results between positive and negative relationships. For instance, Yermark (1996) stated that the empirical examination revealed a negative relationship as the small board size improves the performance; and the discussion revealed that managing the organization and taking decisions become ineffective with the large size of BoD. Similar results were reported by S et al. (2013) and Abdul Rahman and Mustapa (2020). The rational explanation is that the small size will make meetings faster, more frequent, with faster decision making, and fewer conflicts, especially with the CEO. On the other hand, many other studies revealed a positive relationship between BoD size and performance; for instance, Naseem, Rehman, Ikram, and Malik (2017) stated that the larger BoD size has a positive correction with the organizational performance and corporate social responsibility as well. Based on the above discussions, this particular study hypothesized the following argument.

\section{H2: Board size has a significant negative relationship with the firm performance in listed companies in Jordan}

\subsection{CEO duality}

CEO duality is the practice in which the Chief Executive Officer (CEO) possesses both the presidency of the organization as the leader of its own Board of Directors (Chairman). In easier terminology, it's when an organization's CEO uses two hats: the CEO-hat and the Chairman of the Board-hat. CEO Duality undoubtedly affects the firm in inquiry in multiple ways, which might be negative or even positive (Wang, DeGhetto, Ellen, \& Lamont, 2019). There are actually really good explanations to split up both positions in order to boost the total 
stability of the company. When the CEO is actually likewise the seat, a problem of passion arises, as the CEO is actually voting on his/her very own remuneration and the leader can easily determine the activities of the board, which permits for misuse of the leader spot (Vo, 2010). The previous discussions are supported by the agency theory because it is a questionable issue, whether the person with two conflicted power in the organization will make the proper unbiased decisions and whether the personal interest will not correlate the decisions and affect the organization monitoring. So, CEO duality will increase the power of the CEO and if used improperly, it will reduce the board monitoring (Alshirah et al., 2020; Wang, DeGhetto, Ellen, \& Lamont, 2019). However, the stewardship theory has a contradictory explanation and argued that the CEO with two positions will make the decision faster and reduce the time for a long process of making the decision. For instance, some previously found that CEO duality had a significant negative influence on the firms' performance (Mubeen et al., 2020; Wang et al., 2019). In another study by Wang et al. (2019), the results revealed that the CEO duality/separation had no impact on the organizational performance. Based on the above discussions, this particular study hypothesized the following argument.

H3: CEO duality has a significant negative relationship with the firm performance in listed companies in Jordan

\subsection{Conceptual Framework}

Based on the above discussions, this research is composing a predictive model of Tobin's Q based on three BoD antecedents as the independent variables. The regression model has the board independence, board size, and CEO duality as predictors of Tobin's Q. The model is set out as the following equation and Figure 1 shows the hypothesized relationships.

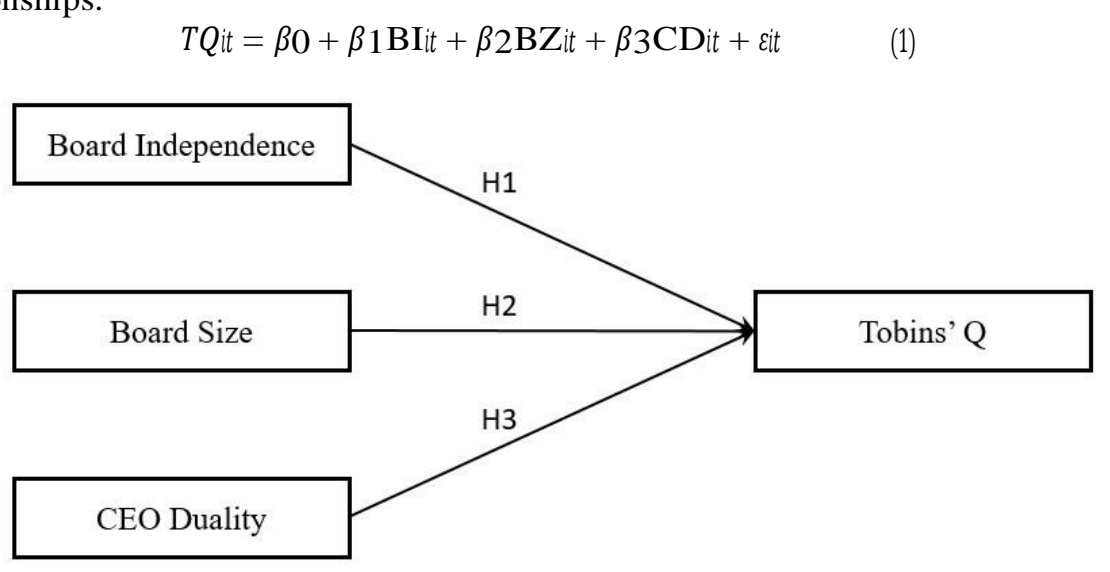

Figure 1. Proposed Conceptual Framework

\subsection{Methodology}

This article is based on quantitative methods that used regression-based analysis for secondary panel data in the context of Amman Stock Exchange (ASE) to examine the relationships between three antecedents; board independence, the board size, and CEO duality; and the firms' performance among the Jordanian listed firms.

The proposed conceptual framework has four variables; three corporate governance variables and the firms' performance. Firms' performance is measure in terms of Tobin's Q as a function of “common stock, the market value of the preferred stock, book value of debt, and total assets". CEO duality is measured as "a dummy variable takes one if the chairman does not hold the position of CEO, otherwise zero". Board size is measured as "the total number of board of directors' members". Board independence is measured as "the proportion of independent members".

The main source for the data is the financial and yearly report for the firms listed in the Amman Stock Exchange (ASE). The time span is 10 years from 2008 to 2018 and the chosen listed companies will only include the companies with full and complete data for the whole period. Any company with any missing data is excluded because it will affect the panel data analysis. Based on this criterion, 180 firms from the non-financial sector are included.

\section{Findings \\ 4.1 Descriptive Statistics}

Table 1 shows the descriptive analysis of the four proposed variables in terms of mean, median, minimum, and maximum. For the three characteristics of the board of directors, $14.1 \%$ of the firms have CEO duality positions but $84.9 \%$ have separations between the CEO and the chairman positions. The maximum CEO duality rate is $25 \%$ and the minimum is $0 \%$. For the board size characteristics, the results show that the size is between 7 and 11 with a mean value of 7.87 . For the board independence, the minimum rate is $0 \%$ and the maximum rate is $65.8 \%$ with an average rate of $58.28 \%$. For Tobin's Q, it seems that most of the companies have a high rate because the maximum rate is 0.999 and the minimum rate is 0.998 with an average of 0.999 . 
Table 1. Descriptive Statistics

\begin{tabular}{|c|c|c|c|c|}
\hline & TQ & BI & BZ & CEO \\
\hline Mean & 0.9990 & 0.5828 & 7.8698 & 0.1407 \\
\hline Median & 0.9990 & 0.6296 & 7.7551 & 0.1557 \\
\hline Maximum & 0.9993 & 0.6580 & 11.0000 & 0.2500 \\
\hline Minimum & 0.9981 & 0.0000 & 7.1143 & 0.0000 \\
\hline Std. Dev. & 0.0001 & 0.0848 & 0.4533 & 0.0421 \\
\hline Skewness & -3.1551 & -1.3504 & 3.0579 & -1.0129 \\
\hline Kurtosis & 29.7357 & 4.3635 & 16.1494 & 3.7163 \\
\hline
\end{tabular}

\subsection{Preliminary Examinations}

This study is regression-based analysis, which has three preliminary tests to be conducted in advance as the following:

- Normality - Skewness, and kurtosis are used and the rule of thumb stated that "data is considered to be normal if the standard skewness is within \pm 1.96 and standard kurtosis is \pm 3 " (Haniffa \& Hudaib, 2006). The results show that some values violated the acceptable level (as seen in Table 1). However, this is possible in the panel data because the regression can have effects.

- Multicollinearity - the rule of thumb is that "the Multicollinearity exists if the correlation between two independent variables is more than 0.90" (Hair, Black, Babin, \& Anderson, 2009). As seen in Table 2, all the correlations are below the threshold value of 0.90 . In addition, the variance inflation factor (VIF), "the VIF $>$ 10 indicates that there is a high level of Multicollinearity" (Gujarati, 2009). The results show that that there are no Multicollinearity issues (as seen in Table 2).

- Homoscedasticity and autocorrelation - the Modified Wald test is used for this test with the rule of thumb that "the value should be higher than the 0.05 significance level for both the Wooldridge and Wald test". Table 2 shows that the data of this particular study have no homoscedasticity and autocorrelation problems.

Table 2. Correlation Matrix

\begin{tabular}{|c|c|c|c|c|c|}
\hline Probability & TQ & BI & BZ & CEO & VIF \\
\hline TQ & 1.000 & & & & \\
\hline BI & $0.176^{*}$ & 1.000 & & & 1.560 \\
\hline & $(0.000)$ & & & & 1.170 \\
\hline BZ & $-0.159^{*}$ & -0.043 & 1.000 & & 1.540 \\
\hline CEO & $(0.000)$ & $(0.055)$ & & & \\
\hline & $0.106^{*}$ & $0.487^{*}$ & $-0.572^{*}$ & 1.000 & \\
\hline
\end{tabular}

Table 3. Findings of Heteroscedasticity and Autocorrelation

\begin{tabular}{|c|c|c|}
\hline & "Wald test for Heteroscedasticity & Wooldridge test for autocorrelation \\
\hline & Chi2 $($ Prob $>$ chi2) & Chi2 (Prob > chi2)" \\
\hline \multirow{2}{*}{ TQ } & 0.237 & 0.845 \\
& $(0.784)$ & $(0.690)$ \\
\hline
\end{tabular}

\subsection{Regression Model Selection}

The regression model could be POLS, Random Effect (REM), or Fixed Effect (FEM). Two tests are used to decide the suitable regression model as the following:

- To decide between REM and POLS, the "Breusch-Pagan Lagrange Multiplier (LM)" test is applied. "If the pvalue is less than 0.05 , the REM is more appropriate than the POLS".

- To decide between REM or FEM, the Hausman test is used. "If the null hypothesis is rejected the FEM model is more appropriate than REM model".

Based on the results in Table 4, Breusch-Pagan Lagrange Multiplier (LM) test revealed that the null hypothesis is rejected, and the random effect model is more applicable. However, the Hausman test revealed that there is no sig level, and the fixed effect model (FEM) is chosen for this particular study. 
Table 4. Regression Model Selection

\begin{tabular}{|c|c|c|}
\hline & $\begin{array}{c}\text { "Breusch-Pagan Lagrange Multiplier (LM) test (POLS or } \\
\text { REM) }\end{array}$ & $\begin{array}{c}\text { Hausman } \\
\text { REM) }\end{array}$ \\
\hline & Chi2 (Prob > chi2) & Chi2 (Prob > chi2)" \\
\hline TQ & $\begin{array}{c}17.897 * \\
(0.000)\end{array}$ & $343.91 *$ \\
& $(0.000)$ \\
\hline
\end{tabular}

\subsection{Regression Analysis Results}

Table 5 shows the results of the three hypotheses based on the fixed-effect model. The relationship is considered acceptable if the significance level is less than $0.05(5 \%)$ or the t statistics value is greater than the results for the three hypotheses are the following.

- Board independence has a significant positive relationship with the firm performance in terms of Tobins' Q in listed companies in Jordan at a level of $1 \%$ with a path coefficient of 0.2640 and statistic value of 8.7623 . Therefore hypothesis 1 is accepted.

- Board size has a significant negative relationship with the firm performance in terms of Tobins' Q in listed companies in Jordan at a level of $1 \%$ with a path coefficient of -0.4830 and a $t$ statistic value of -8.0277 . Therefore hypothesis 2 is accepted.

- The CEO duality has a significant positive relationship with the firm performance in terms of Tobins' Q in listed companies in Jordan at a level of $1 \%$ with a path coefficient of 0.3150 and $t$ statistic value of 4.2478. Therefore hypothesis 3 is accepted and the positive relationship means that more CEO duality enhances firm performance.

Table 5. Regression Analysis Result

\begin{tabular}{|c|c|c|c|c|}
\hline \multicolumn{5}{|c|}{ "Dependent Variable: TQ } \\
\hline Variable & Coefficient & Std. Error & t-Statistic & Prob. \\
\hline BI & $0.2640^{*}$ & 0.0000 & 8.7623 & 0.00000 \\
\hline BZ & $-0.4830^{*}$ & 0.0000 & -8.0277 & 0.00000 \\
\hline CEO & $0.3150^{*}$ & 0.0001 & 4.2478 & 0.00000 \\
\hline C & 0.9992 & 0.0001 & 19858.22 & 0.00000 \\
\hline R-squared & 0.6264 & Mean dependent var & 0.9990 \\
\hline Adjusted R-squared & 0.6120 & S.D. dependent var & 0.0001 \\
\hline S.E. of regression & 0.0001 & Akaike info criterion & -15.7225 \\
\hline Sum squared resid & 0.0000 & Schwarz criterion & -15.7111 \\
\hline Log-likelihood & 15309.87 & Hannan-Quinn criter. & -15.7183 \\
\hline F-statistic & 43.2830 & Durbin-Watson stat & 1.9605 \\
\hline Prob(F-statistic)" & 0.0000 & & & \\
\hline
\end{tabular}

\subsection{Results Discussion}

The first hypothesis stated that board independence has a significant positive relationship with the firm performance in listed companies in Jordan. The results show that the board independence is the third impactor on the Tobins' $\mathrm{Q}$ with the significant level at $1 \%$. The change of one unit in the board independent can improve the Tobins' Q by 0.2640 . Those results are rational and explained by the agency theory and resource dependence theory because the decision-making will be more reliable whenever there is a less personal interest which is achieved by the board's independence. The results are consistent with different previous studies such as Al-ahdal et al. (2020), Naciti (2019), Uribe-Bohorquez et al. (2018), and the Chu, Mathieu, and Mbagwu (2019). The second hypothesis stated that the board size has a significant negative relationship with the firm performance in listed companies in Jordan. The results show that the board size is the first impactor on the Tobins' Q with a significant level of $1 \%$. The change of one unit in the board size can improve the Tobins' Q by 0.4830 . The results are supported by the agency theory because the smaller board size will have better communication and faster decision-making. The results are consistent with different previous studies such as Al Sawalqa (2021), Alshirah et al. (2020), and Abdul Rahman and Mustapa (2020). The third hypothesis stated that the CEO duality has a significant negative relationship with the firm performance in listed companies in Jordan. The results show that the board size is the second impactor on the Tobins' $Q$ with a significant level of $1 \%$. The change of one unit in the board size can improve the Tobins' $\mathrm{Q}$ by 0.3150 . The rational explanation of this argument is supported by 
agency theory because the less conflict of interest, the better decision making, which is achieved by the separation between the CEO and chairman. The results are consistent with different previous studies such as Alshirah et al. (2020), Wang et al. (2019), and Mubeen et al. (2020)

\subsection{Conclusion}

This particular study is an examination of the relationships between three antecedents; board independence, the board size, and CEO duality; and the firms' performance among the Jordanian listed firms. There are few studies in the literature that examined the Jordanian exchange market and the findings of this research contribute to the stakeholders in the Jordanian context. The three relationships in the proposed model were found to be significant with board size having the highest negative impact, followed by CEO duality the board independence and both have a positive impact. The results are in line with the previous studies as discussed earlier in this paper.

The results are useful to management and decision-maker in Jordan and similar markets in the Middle East because it shows that the size of the board negatively affects the performance, which contradicts with the culture of the market. In addition, board independence and CEO duality have a positive impact; policymakers must develop the policies to assure that those conditions are followed in the Jordanian market. The finding also contributes to academics because it provides a more generalization to the relationships in the developing market and provides more data to compare between different markets.

The study can explain $62.64 \%$ of Tobin's Q variance based on three corporate governance variables that are based on the board of directors' structure. For sure the more antecedent variable the more explanation rate; therefore, adding more corporate governance variables such as ownership structure, board meetings, and audit committee will contribute to the proposed conceptual framework. Besides, the proposed design could consider additional moderating variables such as demographic characteristics and the firms' type.

\section{References}

[1].Aduda, J., Chogii, R., \& Magutu, P. O. (2013). An Empirical Test Of Competing Corporate Governance Theories On The Performance Of Firms Listed At The Nairobi Securities Exchange. European Scientific Journal, 9(13), 117-139.

[2].Ahmadi, A., Nakaa, N., \& Bouri, A. (2018). Chief Executive Officer attributes, board structures, gender diversity and firm performance among French CAC 40 listed firms. Research in International Business and Finance, 44, 218-226.

[3].Al Ramahi, N., Alaboud, E., Owais, W., AlRefae, K., \& Shahwan, Y. (2014). The Results of Applying the Principles of Corporate Governance in Corporations Listed on the First Market in the Amman Stock Exchange. Research Journal of Finance and Accounting, 5(14), 41-53.

[4].Al Sawalqa, F. A. (2021). Board mechanisms and corporate market value: Panel data evidence from jordan.

[5].Accounting, 7(2), 257-268. https://doi.org/10.5267/j.ac.2020.12.005

[6].Al-ahdal, W. M., Alsamhi, M. H., Tabash, M. I., \& Farhan, N. H. S. (2020). The impact of corporate governance on financial performance of Indian and GCC listed firms: An empirical investigation. Re search in International Business and Finance, 51, 101083.

[7].Al-Kassar, T. A., \& Al-Nidawiy, M. A. (2014). The Role Of Corporate Governance And Its Impact On The Share Price Of Industrial Corporations Listed On The Amman Stock Exchange. European Journal of Accounting Auditing and Finance Research, 2(6), 106-123.

[8].Almasarwah, A. K. (2015). Earnings Management And Its Relationship With Corporate Governance Mechanisms In Jordanian Industrial Firms. (PhD Thesis), Loughborough University.

[9].Alnajar, A. E. A. (2021). THE ROLE OF GOOD CORPORATE GOVERNANCE IN PREVENTING AND REDUCING FRAUD: DENMARK AND MALAYSIA CASE STUDY. Review of Business,

[10]. Accounting, \& Finance, 1(1), 58-92.

[11]. Alshirah, M. H., Abdul Rahman, A., \& Mustapa, I. R. (2020). Board of directors' characteristics and corporate risk disclosure: the moderating role of family ownership. EuroMed Journal of Business, 15(2), 219-252. https://doi.org/10.1108/EMJB-09-2019-0115

[12]. Amran, A., Ishak, M. S., Zulkafli, A. H., \& Nejati, M. (2010). Board structure and extent of corporate governance statement. International Journal of Managerial and Financial Accounting, 2(4), 383-400.

[13]. Arora, A. (2015). Literature Review Assessing the Relationship between Corporate Governance and Firm Performance. Paper presented at the Compendium of Research Papers of National Conference on Managing tomorrow: Issues and Challenges by DY Patil Institute of Management Studies, Pune.

[14]. Arora, A., \& Sharma, C. (2016). Corporate Governance And Firm Performance In Developing Countries: Evidence From India. Corporate Governance, 16(2), 420-436.

[15]. Arslan, M., \& Alqatan, A. (2020). Role of institutions in shaping corporate governance system: evidence from emerging economy. Heliyon, 6(3), e03520.

[16]. Assenga, M. P., Aly, D., \& Hussainey, K. (2018). The impact of board characteristics on the financial performance of Tanzanian firms. Corporate Governance: The International Journal of Business in Society.

[17]. Bathula, H. (2008). Board Characteristics And Firm Performance: Evidence From New Zealand. (PhD thesis), Auckland University of Technology.

[18]. Chandren, S., Qaderi, S. A., \& Ghaleb, B. A. A. (2021). The influence of the chairman and CEO effectiveness on operating performance: Evidence from Malaysia. Cogent Business \& Management, 8(1), 
1935189.

[19]. Chu, L., Mathieu, R., \& Mbagwu, C. (2019). Independent Directors, Business Risk, and the Informativeness of Accounting Earnings for Debt Contracting. Canadian Journal of Administrative Sciences/Revue Canadienne Des Sciences de l'Administration, 36(4), 559-575.

[20]. Dhamadasa, P., Gamage, P., \& Herath, S. K. (2014). Corporate Governance, Board Characteristics and Firm Performance: Evidence from Sri Lanka. South Asian Journal of Management, 21(1), 7-31.

[21]. Fama, E. F., \& Jensen, M. C. (1983). Agency problems and residual claims. Journal of law and Economics, 26(2), 327-349.

[22]. Fulgence, S. (2021). THE EFFECTS OF BOARD AND OWNERSHIP STRUCTURE ON CORPORATE GOVERNANCE DISCLOSURE: EVIDENCE FROM EAST AFRICAN COUNTRIES.

[23]. Gujarati, D. N. (2009). Basic Econometrics (5th ed.). New York: McGraw-Hill.

[24]. Hair, J. F., Black, W. C., Babin, B. J., \& Anderson, R. E. (2009). Multivariate Data Analysis (7th ed.). New Jersey: Person Prentic Hall.

[25]. Haniffa, R., \& Hudaib, M. (2006). Corporate Governance Structure and Performance of Malaysian Listed Companies. Journal of Business Finance \& Accounting, 33(7-8), 1034-1062.

[26]. Idris, M. I. I. (2012). The Impact Of Ownership Structure And External Audit On Accruals And Real Activities Earnings Management In Jordan. (PhD ), University of Gloucestershire.

[27]. Khorma, T. (2014). The Myth of the Jordanian Monarchy's Resilience to the Arab Spring: Lack of Genuine Political Reform Undermines Social Base of Monarchy. Retrieved 16 Dec 2016, from https://www.swpberlin.org/fileadmin/contents/products/comments/2014C33_kor.pdf

[28]. Kyere, M., \& Ausloos, M. (2021). Corporate governance and firms financial performance in the United Kingdom. International Journal of Finance \& Economics, 26(2), 1871-1885.

[29]. Liu, H., \& Fong, M. W. (2010). Board Characteristics Of Medium And Large Chinese Companies.

[30]. Corporate Governance: The international journal of business in society, 10(2), 163-175.

[31]. Lutfi, Iramani, R., \& MellyzaSilvy. (2014). The role of board of commissioners and transparency in improving bank operational effeciency and profitability. Paper presented at the The 3rd International Conference on Business and Banking Pattaya, Thailand.

[32]. Makhlouf, M. H., Laili, N. H., Ramli, N. A., \& Basah, M. Y. (2017). Board of directors' effectiveness and firm performance: Evidence from Jordan. Research Journal of Finance and Accounting, 8(18), $23-34$.

[33]. Marashdeh, Z. M. S. (2014). The Effect of Corporate Governance on Firm Performance in Jordan. (Ph.D thesis), University of Central Lancashire.

[34]. Matar, M., \& Nauimat, Z. (2014). The Response of The Boards of Directors In the Distressed Jordanian Public Shareholding Companies to The Risk And Repercussions of The Global Financial Crisis. Jordan Journal of Business Administration, 10(1).

[35]. Mubeen, R., Han, D., Abbas, J., \& Hussain, I. (2020). The effects of market competition, capital structure, and CEO duality on firm performance: A mediation analysis by incorporating the GMM model technique. Sustainability, 12(8), 3480.

[36]. Naciti, V. (2019). Corporate governance and board of directors: The effect of a board composition on firm sustainability performance. Journal of Cleaner Production, 237, 117727.

[37]. Naseem, M. A., Xiaoming, S., Riaz, S., \& Rehman, R. U. (2017). Board attributes and financial performance: the evidence from an emerging economy. The Journal of Developing Areas, 51(3), $281-297$.

[38]. Puni, A., \& Anlesinya, A. (2020). Corporate governance mechanisms and firm performance in a developing country. International Journal of Law and Management.

[39]. S, A. O., Olusola, A. G., \& Abiodun, O. F. (2013). Relationship Between Corporate Governance And Organizational Performance: Nigerian Listed Organizations Experience. International Journal of Business and Management Invention, 2(9), 1-6.

[40]. Srivastava, G., \& Kathuria, V. (2020). Impact of corporate governance norms on the performance of Indian utilities. Energy Policy, 140, 111414.

[41]. Uribe-Bohorquez, M.-V., Martínez-Ferrero, J., \& García-Sánchez, I.-M. (2018). Board independence and firm performance: The moderating effect of institutional context. Journal of Business Research, 88, $28-43$.

[42]. Wang, G., DeGhetto, K., Ellen, B. P., \& Lamont, B. T. (2019). Board antecedents of CEO duality and the moderating role of country-level managerial discretion: a meta-analytic investigation. Journal of Management Studies, 56(1), 172-202.

[43]. Warrad, L., Almahamid, S. M., Slihat, N., \& Alnimer, M. (2013). The relationship between ownership concentration and company performance, a case of Jordanian non-financial listed companies. Institute of Interdisciplinary Business Research.

[44]. Yermark, D. (1996). Higher market valuation of companies with a small board of directors. Journal of Financial Economics, 40, 185-221. 